BOOK REVIEW SYMPOSIUM

\title{
CONSTITUTIONS, CITIZENSHIP AND THE SHADOW OF STATELESSNESS
}

\author{
NATALIE BAIRD*

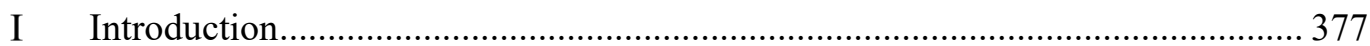

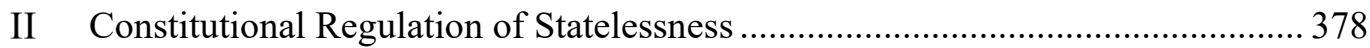

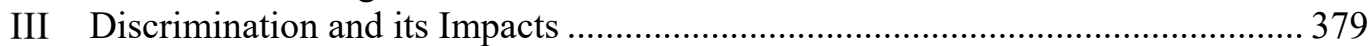 \\ IV Fragmented Citizenship Governance and Human Rights ................................... 381

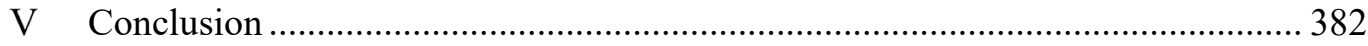

\section{INTRODUCTION}

Jo Shaw's magnificent book, The People in Question: Citizens and Constitutions in Uncertain Times, focuses primarily on what she calls the 'constitutional citizen'. ${ }^{1}$ The stateless individual, defined under international law as 'a person who is not considered as a national by any State under the operation of its law', ${ }^{2}$ is therefore potentially at the periphery of her book. Shaw acknowledges this early on, referring evocatively to the "shadow of statelessness' ${ }^{3}$ and noting that ' $[t]$ he shadowy presence of the non-citizen lurks throughout the book, without being the central focus of analysis'. ${ }^{4}$ Yet, despite the focus on constitutional citizens, there is still plenty of thought-provoking material relevant in some way to the plight of non-citizens. In particular, the breadth and depth of Shaw's analysis prompts reflection on the phenomenon of statelessness.

The inherent nature of statelessness means that it is difficult to be accurate about the extent of the problem. The most recent estimate from the United Nations High Commissioner for Refugees ('UNHCR') of the number of stateless persons was 4.2 million, ${ }^{5}$ but the true extent of statelessness is estimated to be much higher with at least 15 million stateless people globally. ${ }^{6}$ Significant populations of stateless persons include Rohingya in Myanmar and displaced in neighbouring countries, Palestinians, Bidun and Kurds in the Middle East, Roma in Europe, individuals from the former Soviet Bloc and those of Haitian descent in the

* Natalie Baird is an Associate Professor at the School of Law of the University of Canterbury. Email: natalie.baird@canterbury.ac.nz.

1 Jo Shaw, The People in Question: Citizens and Constitutions in Uncertain Times (Bristol University Press 2020) 35.

2 Convention Relating to the Status of Stateless Persons, opened for signature 28 September 1954, 360 UNTS 117 (entered into force 6 June 1960) art 1 ('1954 Convention').

3 Shaw (n 1) 7.

4 ibid 59.

5 Global Trends: Forced Displacement in 2019 (Report, UNHCR 2020) 56 $<$ https://www.unhcr.org/statistics/unhcrstats/5ee200e37/unhcr-global-trends-2019.html >.

6 Statelessness in Numbers: 2020 (Report, Institute on Statelessness and Inclusion 2020) 1 $<$ https://www.institutesi.org/resources/statelessness-in-numbers-2020-an-overview-andanalysis $>$. 
Dominican Republic. ${ }^{7}$ An emerging situation of potential mass statelessness is the Muslim minority in the state of Assam in India. ${ }^{8}$ Causes of statelessness include racial and religious discrimination, armed conflict, gender discriminatory nationality laws, arbitrary deprivation of citizenship, state succession, lack of birth registration and inter-generational statelessness. The consequences of statelessness can include deportation, forced displacement, trafficking, inability to access government-funded services such as health and education, and an inability to own property, get government jobs, or work in certain professions. ${ }^{9}$ Or, to put it within a constitutional citizenship framework, statelessness means a lack of membership in a political community and a consequent lack of equality before the law. As famously described by Hannah Arendt, it is the absence of the 'right to have rights'. ${ }^{10}$

This review offers three observations on Shaw's work and its linkages to the problem of statelessness. The first observation concerns the ways in which constitutions currently regulate (or do not regulate) those who are stateless. The second is on the pivotal impact of discrimination (racial, religious and gender) on both citizenship and statelessness. Finally, and more optimistically, this review considers whether the fragmented nature of citizenship governance identified by Shaw may open discursive spaces for progress on statelessness as well as citizenship.

\section{Constitutional Regulation of StAtelessness}

Shaw points out that detailed constitutional regulation of citizenship is relatively rare, ${ }^{11}$ despite it being such a significant element of a constitutional framework. The lack of constitutional regulation is also true - even more so - for stateless persons. Around 30 constitutions mention statelessness or stateless persons in some way. ${ }^{12}$ These references typically fall into one of four categories. ${ }^{13}$ Some constitutions provide that citizenship will be granted if someone would otherwise be stateless, or that there will be no deprivation of citizenship if the consequence would be to leave a person stateless. This type of provision aimed at preventing statelessness, and reflecting the Convention on the Reduction of Statelessness ('1961 Convention'), ${ }^{14}$ arises especially in regions of the world that are post-

7 For more perspectives on each of these situations of statelessness, see generally Katalin Berényi, 'Mapping Minorities' Vulnerability to Hate Speech and Denationalisation with a Focus on East and Southeast Asia' (2020) 2(1) Statelessness \& Citizenship Review 5, 14-23; Nicoletta Enria, 'Resisting Erasure: the Politics of Reckoning with Statelessness in the Arts' (2019) 1(2) Statelessness \& Citizenship Review 315; José-María Arraiza, Phyu Zin Aye, Marina Arraiza Shakirova, 'Fighting Imagined Invasions with Administrative Violence: Racism, Xenophobia and Nativism as a Cause of Statelessness in Myanmar, the Dominican Republic and Assam (India)' (2020) 2(2) Statelessness \& Citizenship Review 194.

8 See Talha Abdul Rahman, 'Identifying the 'Outsider': An Assessment of Foreigner Tribunals in the Indian State of Assam’ (2020) 2(1) Statelessness \& Citizenship Review 112.

9 Shaw (n 1) 245.

10 Hannah Arendt, The Origins of Totalitarianism (Harcourt, Brace and World 1968) 296.

11 Shaw (n 1) 37.

12 Natalie Baird, 'Stateless Person' in Rainer Grote, Frauke Lachenmann and Rüdiger Wolfrum (eds), Max Planck Encyclopedia of Comparative Constitutional Law (Oxford University Press 2019) [12].

13 ibid [13]-[16].

14 Convention on the Reduction of Statelessness, opened for signature 30 August 1961, 989 UNTS 185 (entered into force 13 December 1975) ('1961 Convention'). 
conflict or post-transition. ${ }^{15}$ Other provisions provide that the rights and freedoms of citizens are also available to stateless persons. Contrastingly, sometimes there are constitutional exclusions from rights protections for those who are stateless, including limits on political rights and the ability to own property. The fourth type of reference is to stateless persons being able to seek asylum or receive protection from expulsion or deportation alongside refugees and asylum seekers.

Although it is surprising that constitutional references to citizenship are relatively light given the importance of 'the people' to the constitutional enterprise, the lack of explicit reference to stateless people is less unexpected. Almost by definition, stateless people are not 'the people' with whom a constitution is intimately connected; 'the people in question' are not those who are stateless. Equally, no state makes creating statelessness into a constitutional objective, although as Shaw notes, it can readily become the core by-product of 'constitutional exclusivity'. ${ }^{16}$ In this sense, the fact that over 30 constitutions refer to stateless persons, and many in an inclusionary rather than an exclusionary manner, seems promising.

Having said that, the potential implications for stateless people in those states where the constitution is silent on their status are significant. Where the constitution is protective of those who are stateless, either by according citizenship or access to rights, then this provides a constitutional bulwark. If there is no constitutional reference to those who are stateless, then their plight is left to the whim of politicians, judges or bureaucrats of the day. As Shaw notes, even in those constitutions that make comprehensive reference to citizenship, much of the detail of citizenship regulation is often determined by the legislature. ${ }^{17}$ In the current environment, the perils of a populist legislature are a particular risk, with tyranny of the majority a very real prospect. Equally, administrative, procedural and bureaucratic measures can have a profound negative impact and result in precarious outcomes for those who are stateless. While explicit constitutional reference to those who are stateless may therefore be useful, this can still be undermined on the ground by political, judicial, administrative and bureaucratic actions. As Julija Sardelić notes in her comment, the dynamic of constitutional citizenship can work to enhance equality and dignity of all human beings (including those who are stateless), but it can also undermine it. ${ }^{18}$

\section{DISCRIMINATION AND ITS IMPACTS}

The second observation prompted by Shaw's book is the profound impact of discrimination - racial, religious and gender in particular — on both citizenship and statelessness. As Shaw points out, states have been manipulating citizenship in 'the national interest' for as long as it has existed as a constitutional phenomenon, with almost every instance of decolonisation involving an element of 'engineering' of citizenship, often based on problematic 'ethnic' choices. ${ }^{19}$

15 Shaw (n 1) 146.

16 ibid.

17 ibid 40.

18 Julija Sardelić, 'Citizenship, Constitutions and Peoples on the Margins' (2020) 2(2) Statelessness \& Citizenship Review 384, 387.

19 Shaw (n 1) 185. 
Many of the intractable statelessness situations arise in the context of entrenched discrimination - especially against ethnic minorities. ${ }^{20}$ The application of racially defined preferences, plus other ethnically based restrictions, has produced large populations of stateless or marginalised people. ${ }^{21}$ Notable examples are the Rohingya in Myanmar, and Haitians in the Dominican Republic. As pointed out by Kriszta Kovács in her comment, even where citizenship practices are externally-focused and concerned with widening the citizenship catchment, for ethnonational populists, ethnicity is the key factor for nonresidential citizenship. ${ }^{22}$ Unfortunately, given the huge deference to state sovereignty in the area of nationality and citizenship, explicit and overt racial discrimination is tolerated and sometimes even condoned. A good example of this can be found in art 1(2) of the International Convention on the Elimination of All Forms of Racial Discrimination, which provides that the Convention 'shall not apply to distinctions, exclusions, restrictions or preferences made by a State Party to this Convention between citizens and non-citizens'. ${ }^{23}$ This hands-off approach at the international level has historically enabled states to act with impunity when it comes to both citizenship and statelessness.

This impunity can currently be observed with the populist Indian Government of Prime Minister Narendra Modi and the ruling Bharatiya Janata Party in the Indian state of Assam, where discrimination on various grounds including religion, ethnicity and language linked to the rebuilding of the National Register of Citizens ('NRC') has been ongoing for some years. ${ }^{24}$ Up to two million people were left off the August 2019 draft of the NRC in Assam, including many from the Muslim minority. This raises the prospect of detention, deportation to Bangladesh and statelessness. An amendment to the citizenship legislation in December 2019 has improved the prospects of citizenship registration for many of these two million, but not for those who are Muslim. ${ }^{25}$

Gender discrimination in the context of both citizenship and statelessness is in some ways a less entrenched area of discrimination than race or religion. Gender discriminatory nationality laws that prevent mothers from passing on their nationality to their children are a key cause of childhood statelessness and intergenerational statelessness. Although some problematic situations remain, ${ }^{26}$ gender discriminatory nationality laws have 'toppled like dominoes around the globe' in recent years. ${ }^{27}$ There are now only 25 countries that still deny women the right to

20 Allison Bartlett, 'An Endless Quest for a Home: The Gap in Protection between Stateless Persons and Refugees' [2012] 33 Immigration and Nationality Review 445, 447, 467.

21 Shaw (n 1) 118.

22 Kriszta Kovács, 'People, Sovereignty and Citizenship: The Ethnonational Populists' Constitutional Vocabulary' (2020) 2(2) Statelessness \& Citizenship Review 389.

23 International Convention on the Elimination of All Forms of Racial Discrimination, opened for signature on 21 December 1965, 660 UNTS 195 (entered into force 4 January 1969).

24 See Regina Menachery Paulose, 'A New Dawn? Statelessness and Assam' (2019) 7(1) Groningen Journal of International Law 99.

25 See generally 'Shoot the Traitors' - Discrimination against Muslims under India's New Citizenship Policy (Report, Human Rights Watch April 2020) $<$ https://www.hrw.org/report/2020/04/09/shoot-traitors/discrimination-against-muslimsunder-indias-new-citizenship-policy>.

26 See, eg, Subin Mulmi and Sarah Shneiderman 'Citizenship, Gender and Statelessness in Nepal: Before and After the 2015 Constitution' in Tendayi Bloom, Katherine Tonkiss and Phillip Cole (eds), Understanding Statelessness (Routledge 2017) 135-52.

27 Zahra Albarazi and Laura van Waas, 'Towards the Abolition of Gender Discrimination in Nationality Laws' (2014) 46 Forced Migration Review 49, 49-50. 
confer their nationality on their children on an equal basis with men. ${ }^{28}$ Illustrating the positive impact of international efforts, key milestones in helping to overturn gender discriminatory nationality laws have been the adoption of the Convention on the Elimination of All Forms of Discrimination against Women in 1979,29 and the launch of the Global Campaign for Equal Nationality Rights in $2014 .{ }^{30}$ At the national level, constitutional amendment has become a central part of the toolkit of gender equality, but as Shaw notes, 'constitutions globally hold a more consistent baseline in relation to the inclusion of equality as a principle than they do in relation to citizenship'. ${ }^{31}$ The prospects for reform of constitutional (and legislative) provisions on citizenship, nationality and statelessness, remain dogged by the spectre of state sovereignty.

\section{FragmENTED CITIZENSHIP GOVERNANCE AND HUMAN RigHTS}

A key paradox identified by Shaw is that alongside the rise of populism, many dimensions of globalisation still continue to flourish. ${ }^{32}$ In particular, Shaw argues that there has been a reconfiguration or transformation of the character of citizenship with new norms emerging at the subnational, national, regional and international levels, such that there is now multilevel governance of citizenship. ${ }^{33}$ An exciting prospect is that this fragmentation of governance might therefore open up discursive spaces for contesting citizenship with the result that states' absolute sovereignty in citizenship matters may be eroded. This third observation considers what this fragmentation might mean for the problem of statelessness.

An important aspect of this emerging multilevel governance is that international norms relating to citizenship are evolving. ${ }^{34}$ Shaw points out that questions of citizenship have not typically been prominent in the context of either international development work or international human rights promotion. ${ }^{35} \mathrm{In}$ some ways, this is in contrast to the issue of statelessness, which has received more international attention - illustrated in the aftermath of World War Two with the adoption of the 1954 Convention Relating to the Status of Stateless Persons and the 1961 Convention, ${ }^{36}$ admittedly then followed by a period of lack of international visibility, but now more firmly on the international agenda with the UNHCR mandate for stateless persons, the Global Action Plan to End Statelessness 2014-2024 and UNHCR's HIBelong campaign. ${ }^{37}$ However, one of

28 Background Note on Gender Equality, Nationality Laws and Statelessness 2020 (Background Note, UNHCR 2020) 2 <https://www.refworld.org/docid/5f0d7b934.html >.

29 Convention on the Elimination of All Forms of Discrimination against Women, opened for signature on 18 December 1979, 1249 UNTS 13 (entered into force 3 September 1981).

30 See Global Campaign for Equal Nationality Rights (Web Page) $<$ https://equalnationalityrights.org/>. For earlier international initiatives targeting gender discriminatory nationality laws, see Deirdre Brennan, 'Feminist Foresight in Statelessness: Century-Old Citizenship Equality Campaigns' (2020) 2(1) Statelessness and Citizenship Review 43.

31 Shaw (n 1) 148.

32 ibid 222.

33 ibid 224-25.

34 ibid 251.

35 ibid 148.

361951 Convention (n 2); 1961 Convention (n 14).

37 See generally Global Action Plan to End Statelessness: 2014-2024 (Report, UNHCR 2014); '\#IBelong Campaign to End Statelessness', United Nations High Commissioner for Refugees (Web Page) <https://www.unhcr.org/en-au/ibelong-campaign-to-end-statelessness.html $>$. 
the challenges for the continued international visibility of statelessness is framing it as a human rights issue. ${ }^{38}$

Increased international interest in and scrutiny of citizenship as a human rights issue is therefore likely to be beneficial for addressing statelessness. Scholars have argued for a rights-based approach to citizenship which may perhaps lead to an international law of citizenship or even an international right to citizenship. ${ }^{39}$ Of particular interest here for those who are stateless is the idea of a ius nexi route to citizenship which recognises the proximity or connectedness of a person to a polity, ${ }^{40}$ or a genuine and effective link. ${ }^{41}$ Encouraging developments addressing both citizenship and statelessness in rights terms include regional human rights decisions in Africa, the Americas and Europe. ${ }^{42}$

However, even though there is a discernible move away from citizenship as being solely within the regulatory domain of states, what does a 'global governance' approach have to offer? Shaw notes that the case is currently not very strong for arguing that there is an emergent 'constitutionalised' framing of citizenship practices at the global level as a result of the effects of international law or a decisive 'global' reframing of constitutional citizenship. ${ }^{43}$ But, have international norms on citizenship 'leaked in' (using Shaw's colourful term) to national constitutions? ${ }^{44}$ On the one hand, it is clear that the current Westphalian system of state sovereignty in relation to membership is not going to collapse any time soon. On the other, the interest of the international community in constitutional law and citizenship practices is strengthening and being expressed in innovative and creative ways. A good example of this is the attempt earlier this year by the United Nations High Commissioner for Human Rights to intervene in Supreme Court proceedings in India on the citizenship registration process in Assam. ${ }^{45}$ More of this type of intervention will assist in international norms shaping and strengthening national constitutional frameworks - to the benefit of both citizenship and statelessness.

\section{CONCLUSION}

Shaw observes that 'citizenship is always likely to disappoint those who invest in it the hopes that it will deliver equality and inclusion'. ${ }^{46}$ In her contribution, Johanna Hase also observes that Shaw's notion of constitutional citizenship has

38 Michelle Foster and Hélène Lambert, 'Statelessness as a Human Rights Issue: A Concept Whose Time Has Come’ (2016) 28(4) International Journal of Refugee Law 564.

39 See for example Peter J Spiro, 'A New International Law of Citizenship' (2011) 105(4) American Journal of International Law 694; Barbara von Rütte, 'From State Privilege to Right - A Proposal for Reinterpreting the Right to Citizenship' (Conference Paper, Rights and Status: The Role of Citizenship in Immigrant Integration and Diaspora Building, 29-30 November 2018).

40 Ayelet Shachar, The Birthright Lottery: Citizenship and Global Inequality (Harvard University Press 2009).

41 Jeffrey L Blackman, 'State Successions and Statelessness: The Emerging Right to an Effective Nationality under International Law' (1998) 19(4) Michigan Journal of International Law 1141.

42 Shaw (n 1) 247-51.

43 ibid 242.

44 ibid 223.

45 Priya Pillai, 'Intervention of the UN High Commissioner for Human Rights at the Indian Supreme Court: International Law and the Citizenship Amendment Act', Opinio Juris (Blog Post, 5 March 2020).

46 Shaw (n 1) 190. 
its own conceptual and empirical limits. ${ }^{47}$ While there is certainly a healthy dose of realism in both these observations, for those who are stateless, what constitutional citizenship and citizenship more broadly do at least offer is a chance to emerge from the shadows. Pursuit of more inclusive constitutions, laws and citizenship practices that enable those who are stateless to belong to 'the people in question' is therefore an important goal. Shaw's book offers much food for thought for such endeavours.

47 Johanna Hase, 'The Constitutional Citizen in Narratives of Peoplehood' (2020) 2(2) Statelessness \& Citizenship Review 372, 375. 